\title{
Effects of phosphorus fertilization and Pseudomonas fluorescens strain on the growth and yield of faba bean (Vicia faba L.)
}

\author{
Efecto de la aplicación de fósforo y cepas de Pseudomonas fluorescens en el \\ desarrollo y producción de haba (Vicia faba L.)
}

\author{
Somayeh Ghasempour Nikfarjam ${ }^{1 *}$, Hashem Aminpanah ${ }^{2}$
}

\begin{abstract}
A field experiment was conducted in Lihijan, Iran in 2013 to evaluate the effect of phosphorus fertilization (P) and Pseudomonas fluorescens strain on the growth and yield of the faba bean. The experiment used a randomized complete block design with a factorial treatment arrangement and three replicates. The experimental factors were phosphorus application $\left(0\right.$ and $\left.25 \mathrm{~kg} \mathrm{ha}^{-1}\right)$ and $P$. fluorescens strains (non-inoculated, strain 136, and strain 168). ANOVA showed a significant interaction effect of $\mathrm{P}$ and $P$. fluorescens strain on plant height, pod number per plant, 100 grain weight, pod length, and pod and grain yield. ANOVA also showed that grain number per pod was significantly affected by $\mathrm{P}$ application and $P$. fluorescens strain, while haulm yield was significantly affected only by $P$. fluorescens strain. In the absence of $\mathrm{P}$, the grain yield of inoculated plants was not significantly different from that of non-inoculated plants. In the presence of $\mathrm{P}\left(25 \mathrm{~kg} \mathrm{ha}^{-1}\right)$, strain 168 showed an increase in grain yield of $42 \%$ and $65 \%$ over strain 136 and non-inoculated plants, respectively. The results indicated that application of phosphorus $\left(25 \mathrm{~kg} \mathrm{ha}^{-1}\right)$ and seed inoculation with $P$. fluorescens strain 168 can be recommended to increase grain/pod yield significantly.
\end{abstract}

Key words: Faba bean, phosphorus, Pseudomonas fluorescens, yield.

\section{RESUMEN}

El experimento de campo fue llevado a cabo en Lihijan, Irán en 2013 con el objetivo de evaluar el efecto de la aplicación de fósforo $(P)$ y Pseudomonas fluorescens en el desarrollo y rendimiento de un cultivo de haba. El diseño experimental fue de bloques completos al azar con arreglo factorial $2 \times 3$, con tres repeticiones. Los factores experimentales fueron la aplicación de fósforo (0 y $25 \mathrm{~kg} \mathrm{ha}^{-1}$ ) y cepas de P. fluorescens cepas (no inoculados, cepa 136 y cepa 168). El ANOVA mostró un efecto interactivo significativo de $P$ y cepa de $\mathrm{P}$. fluorescens en altura de la planta, número de vainas por planta, peso del 100 granos, longitud de vaina y el rendimiento de vaina y grano. SE observó que el número de granos por vaina se vio afectado significativamente por la aplicación de fósforo y cepa de $\mathrm{P}$. fluorescens cepa, mientras que el rendimiento del tallo sólo fue significativamente afectada por la cepa de P. fluorescens. En ausencia de P, el rendimiento de grano de plantas inoculadas fue igual que en plantas no inoculadas. En presencia de $P\left(25 \mathrm{~kg} \mathrm{ha}^{-1}\right)$, la cepa 168 mostró un aumento en el rendimiento de grano de $42 \%$ y $65 \%$, en comparación a las plantas inoculadas con la cepa 136 y las plantas no inoculadas, respectivamente. Los resultados sugieren que la aplicación de fósforo $\left(25 \mathrm{~kg} \mathrm{ha}^{-1}\right.$ ) y la inoculación de semillas con $\mathrm{P}$. fluorescens cepa 168 se puede recomendar para incrementar el rendimiento de vainas y grano en un cultivo de habas.

Palabras clave: haba, fósforo, Pseudomonas fluorescentes, rendimiento.

\section{Introduction}

With protein contents of $12 \%$ to $32 \%$, legume crops play an important role in human nutrition. Faba bean is an annual winter crop in temperate and subtropical regions; it was cultivated globally over an area of 7.3 million hectares in 2012 and produced a mean yield of $1174 \mathrm{~kg} \mathrm{ha}^{-1}$. In Iran 8000 ha are under cultivation with faba bean, with a mean yield of $2125 \mathrm{~kg} \mathrm{ha}^{-1}$ (dry beans). Faba bean has four main functions in agro-ecosystems: (1) providing food and feed that is rich in protein; (2) supplying $\mathrm{N}$ to agroecosystems by symbiotic $\mathrm{N}_{2}$ fixation with Rhizobium bacteria to increase soil fertility; (3) diversifying the crop system to reduce constraints on growth and yield by the other crops in the rotation; and (4) reducing fossil energy consumption for crop production. The faba bean is also grown for green manure and can

1 Department of Agronomy and Plant Breeding, Guilan Science and Research Branch, Islamic Azad University. Rasht, Iran.

2 Department of Agronomy and Plant Breeding, Rasht Branch, Islamic Azad University. P.o.Box: 41335-3516, Tel: 00981314222153, Fax: 00981314227060. Rasht, Iran.

* Corresponding Author: aminpanah@iaurasht.ac.ir

Fecha de Recepción: 28 Julio, 2015.

Fecha de Aceptación: 18 Agosto, 2015. 
significantly increase the yields of cereal and other crops (Wani et al., 1994).

Adequately balanced amounts of nutrients are essential to achieve maximum productivity. Phosphorus $(\mathrm{P})$ is an essential element for crops with greatly decreased uptake from fixation with mineral ions such as aluminum, iron, calcium and magnesium (Feng et al., 2004). Plants can only absorb $\mathrm{P}$ as $\mathrm{H}_{2} \mathrm{PO}_{4}^{-1}$ or $\mathrm{HPO}_{4}{ }^{-2}$, which are mostly present in very low concentrations in the soil (Bhattacharyya and Jha, 2012). P plays a structural role in the nucleus and cell membrane (Raghothama and Karthikeyan, 2005). A large percentage of $\mathrm{P}$ from chemical phosphate fertilizers is not available to plants because at least $70-90 \%$ of $\mathrm{P}$ that enters the soil is fixed by $\mathrm{Fe}, \mathrm{Al}$, and $\mathrm{Ca}$ in soils (McBeath et al., 2006). The lack or low rate of essential elements such as $\mathrm{P}$ and potassium in the soil negatively affect growth and the nitrogen fixation rate. Bolland et al. (2000) reported that $\mathrm{P}$ fertilizer increased crop yield $50 \%$ to $100 \%$ because of the increased number of pods per plant. Turk and Tawaha (2002) applied different rates of $\mathrm{P}(0,17.5$, 35 and $52.5 \mathrm{~kg} \mathrm{ha}^{-1}$ of phosphorus oxide) to faba beans and obtained the highest yield at $52.5 \mathrm{~kg} \mathrm{ha}^{-1}$. They reported application of $\mathrm{P}$ to faba bean plants significantly increased 100 grain weight, grain number per pod and pod number per plant.

Bacteria of the genus Pseudomonas are widely distributed in soil and can colonize plant rhizospheres to produce different metabolites. Studies have found that the most important characteristic in promoting plant growth is phosphate-solubilizing bacteria (Rashid et al., 2004). These bacteria are usually present around the roots and assist in nutrient uptake by the plants. The use of growth-promoting bacteria can increase the growth and yield of crops through direct and indirect mechanisms. It has been proven that these bacteria increase the qualitative/quantitative yields of most crops through biological fixation of nitrogen, biological control of plant pathogens (Saravanakumar et al., 2007; Dey et al., 2004), vitamin production, increased iron absorption by siderophore secretion (Shaharoona et al., 2008; Braud et al., 2009) and production of the plant hormones cytokinin, auxin and gibberellin (Dey et al., 2004), decreasing levels of ethylene by production of Acc deaminase (Shaharoona et al., 2008) and increasing phosphorus solubility. Previous studies have shown that co-inoculation of phosphate-solubilizing bacteria (PSB) with other growth-promoting rhizobacteria decreased phosphate fertilizer consumption by $50 \%$ without a significant reduction in grain yield (Jilani et al., 2007; Yazdani et al., 2009). The ability of Pseudomonas to solubilize $\mathrm{P}$ affects the yield, growth parameters, and $\mathrm{P}$ uptake of faba beans (Crowley, 2006). Pseudomonas species have been shown to increase the number and dry weight of the nodes, grain yield, yield components, and availability and uptake of elements in soybeans (Son et al., 2006). Dey et al. (2004) reported that Pseudomonas strains increased pod yield by $18 \%$ to $26 \%$. Saharan et al. (2010) reported a $46 \%$ increase in Vigna yield using Pseudomonas R81. In a pot experiment with mung bean, Sharma et al. (2003) reported that the Pseudomonas strain GRP3 increased the yield of shoots by $101 \%$, roots by $39 \%$ and chlorophyll content by $40 \%$.

To date few studies have examined the effect of simultaneous application of $\mathrm{P}$ and Pseudomonas strains on the growth and yield of faba bean. This experiment examined the effect of P rate and Pseudomonas strain on the growth and yield of the faba bean.

\section{Materials and methods}

\section{Experimental site and design, crop management, and sampling}

The present study was conducted during the 2013-2014 growing season in Lahijan in the Guilan province of Iran (longitude $50^{\circ} \mathrm{OE}$, latitude $37^{\circ}$ $11 \mathrm{~N})$. The physical and chemical properties of the soil $(0-30 \mathrm{~cm})$ were $0.78 \%$ organic matter content, $15 \%$ clay, $49.5 \%$ silt, $35.5 \%$ sand, $7.7 \mathrm{pH}$, total $\mathrm{N} 0.07 \%$, available phosphorous $10.5 \mathrm{mg} \mathrm{kg}^{-1}$, available potassium $148.0 \mathrm{mg} \mathrm{kg}^{-1}$ and EC $0.43 \mathrm{ds}$ $\mathrm{m}^{-1}$. Weekly precipitation and mean temperature (maximum, minimum and average) are shown in Figures 1 and 2, respectively. The experiment was performed as a randomized complete block design with a factorial treatment arrangement with three replicates. The experimental factors were phosphate fertilizer application $\left(0\right.$ and $\left.25 \mathrm{~kg} \mathrm{ha}^{-1}\right)$ and Pseudomonas strain (un-inoculated, Pseudomonas fluorescens strain 136, and Pseudomonas fluorescens strain 168). Phosphorus was applied as triple superphosphate fertilizer using the strip method. Pseudomonas bacteria were obtained from the Soil and Water Research Institute, Karaj, Iran and used as instructed. The field was prepared using two perpendicular disks and a leveling step. Nitrogen and potassium fertilizers were added before sowing based on the results of soil testing. Each plot was 4 


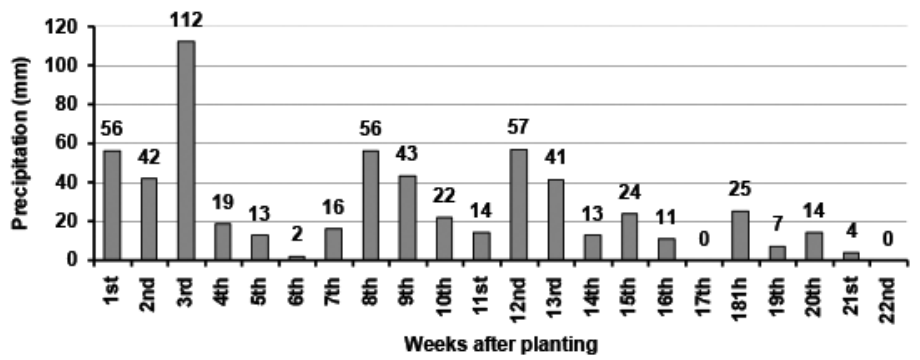

Figure 1. Weekly precipitation during faba bean growing period

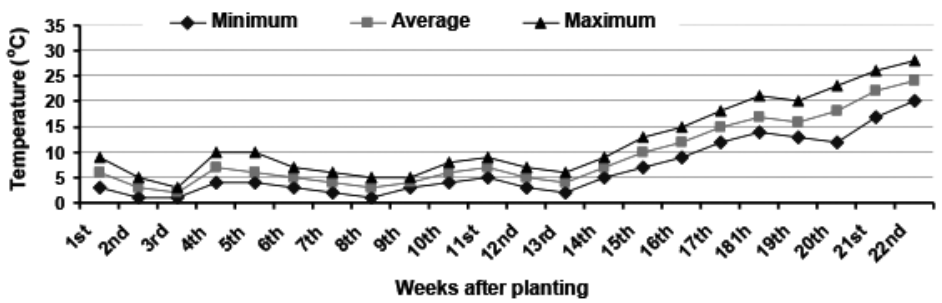

Figure 2. Weekly temperatures (maximum, minimum and mean) during the faba bean growing period

$\times 2 \mathrm{~m}$ with a planting distance of $20 \times 50 \mathrm{~cm}$. The two plots were $70 \mathrm{~cm}$ apart and the distance between repeats was $1 \mathrm{~m}$. The bean seeds (variety Barkat) were cultivated at a depth of $5 \mathrm{~cm}$. Crop protection (control of pests and diseases) was performed as needed during the crop growing period. Manual weeding was carried out in each plot. The border lines were excluded when measuring plant height; 5 plants were randomly selected and the distance from soil surface to end of main stem was measured and recorded in $\mathrm{cm}$. The mean heights of 5 plants in a plot were reported as plant height. Similarly, pod number per plant, grain number per pod, dry weight of 100 grains, haulm yield and pod/grain yield were determined after excluding the border lines by randomly selecting 10 plants from each plot.

\section{Statistical analysis}

Data were subjected to analysis of variance (ANOVA) using SAS software (SAS, 2004) based on a factorial trial and randomized complete block design. The means were compared using LSD testing. The figures were drawn using Excel 2003.

\section{Results and discussion}

\section{Plant height}

ANOVA showed that the effect of $\mathrm{P}$ application on plant height was not significant, while the effect of $P$. fluorescens strain and the interaction of the two factors were significant (Table 1). In the absence

Table 1. Mean squares of ANOVA for plant height $(\mathrm{H})$, pod number per plant $(\mathrm{PN})$, grain number per pod (GN), hundred grain weight (HGW), pod length (PL), Haulm yield (HY), pod yield (PY), and grain yield (GY) as affected by phosphorus rate and Pseudomonas fluorescens strain

\begin{tabular}{lccccccccc}
\hline S.O.V & df & H & PN & GN & HGW & PL & HY & PY & GY \\
\hline R & 2 & $22^{\text {ns }}$ & $1^{\text {ns }}$ & $0.03^{\text {ns }}$ & $78^{\text {ns }}$ & $0.1^{\text {ns }}$ & $38^{\text {ns }}$ & $14937188^{\text {ns }}$ & $7758794^{\text {ns }}$ \\
Phosphorus rate (P) & 1 & $10^{\text {ns }}$ & $34^{* *}$ & $0.16^{* *}$ & $122^{\text {ns }}$ & $12^{* *}$ & $9614^{\text {ns }}$ & $295787949^{* *}$ & $146952653^{* *}$ \\
P.fluorescens strain (S) & 2 & $144^{* *}$ & $68^{\text {ns }}$ & $0.24^{* *}$ & $726^{* *}$ & $1.5^{* *}$ & $500619^{* *}$ & $200677752^{* *}$ & $67561897^{* *}$ \\
P $\times$ S & 2 & $353^{* *}$ & $44^{\text {ns }}$ & $0.03^{\text {ns }}$ & $689^{* *}$ & $5.1^{* *}$ & $5627^{\text {ns }}$ & $95601942^{* *}$ & $79611150^{* *}$ \\
Error & 17 & 10 & 2 & 0.01 & 89 & 0.3 & 10881 & 6126719 & 2666268 \\
CV $(\%)$ & - & 2.2 & 5.4 & 3.8 & 8.1 & 4.8 & 7.6 & 5.4 & 7.0 \\
\hline
\end{tabular}

*, ** represent significance at 0.05 and 0.01 probability level, respectively. ns represents no significant difference. 
of $\mathrm{P}$, the seed inoculated plants with $P$. fluorescens strain 168 and strain 136 showed greater plant heights than the un-inoculated plants (Figure 3 ). When $\mathrm{P}$ was applied, the plants inoculated with strain 168 recorded the greatest height; the lowest plant height was observed for un-inoculated plants (Figure 3). Phosphorus plays an important role in the initial establishment of a plant, meristematic activity, and cell division. Increased plant height by inoculation of Pseudomonas along with $\mathrm{P}_{2} \mathrm{O}_{5}$ may possibly be attributed to the inoculation-induced increase in indole acetic acid and gibberellic acid production, which subsequently increased the cell division and cell elongation (Afzal et al., 2010). Moreover, it appears that Pseudomonas increases plant height by increasing phosphorus solubility and its availability to plants. These results are consistent with those of other researchers (Afzal et al., 2010).

\section{Pod number per plant}

ANOVA showed that the number of pods per plant was significantly influenced by the effects of $\mathrm{P}$ application, $P$. fluorescens strain and their interaction (Table 1). In the absence of P, Pseudomonas 136 produced the largest number of pods per plant (30.4 \pm 0.5 ). However, no significant difference in number of pods was found between plants inoculated with strain 168 and un-inoculated plants (Figure 4). In contrast, after application of $\mathrm{P}\left(25 \mathrm{~kg} \mathrm{ha}^{-1}\right)$, plants inoculated with $P$. fluorescens strain $168(32.8 \pm 0.6)$ and strain $136(30.5 \pm 0.7)$ recorded the greatest number of pods per plant and the un-inoculated plants recorded the fewest pods per plant $(26.3 \pm$ 1.1). Figure 4 shows that the greatest number of pods per plant was obtained at a $\mathrm{P}$ application rate of $25 \mathrm{~kg} \mathrm{ha}^{-1}$ and inoculation with $P$. fluorescens

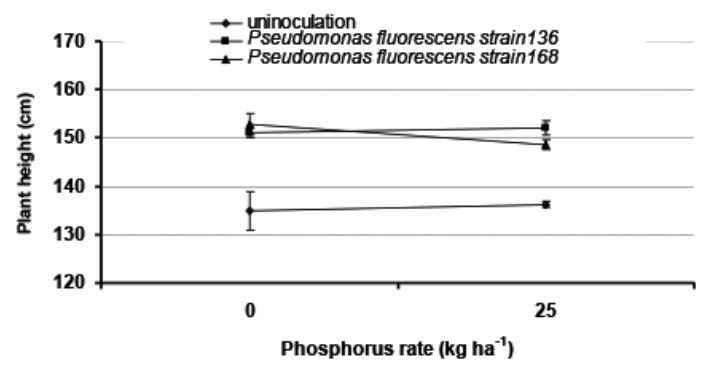

Figure 3. phosphorous rate $\times$ Pseudomonas fluorescens strain interaction effect on plant height. Vertical bars represent \pm 1 SE of means.

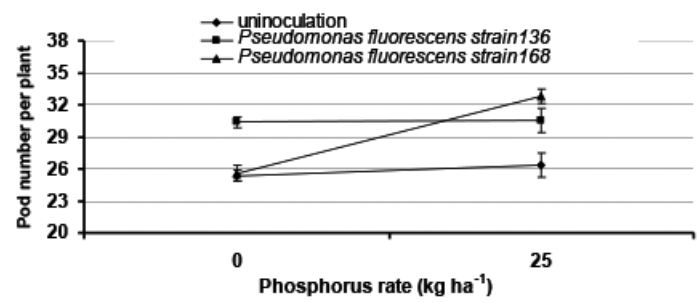

Figure 4. phosphorous rate $\times$ Pseudomonas fluorescens strain interaction effect on pod number per plant. Vertical bars represent \pm 1 SE of means.

strain 168. Previous studies have suggested that $P$ increases flowering and fruit setting; thus the number of pods per plant increased with the application of P. Sing et al. (2011) also found that the effect of $\mathrm{P}$ amount was significant at a probability level of 5\% and that the number of pods per plant increased as the $\mathrm{P}$ application rate increased.

\section{Grain number per pod}

The effects of amount of $\mathrm{P}$ and $P$. fluorescens strain on the number of grains per pod were significant at the $1 \%$ probability level, but their interaction was not significant (Table 1). The application of $\mathrm{P}$ significantly increased the number of grains per pod by $8 \%$ (Table 2). Plants inoculated with $P$. fluorescens 168 recorded the largest number of grains per pod (2.8 grains pod $\left.{ }^{-1}\right)$ and un-inoculated plants and plants inoculated with $P$. fluorescens stain136 recorded the fewest grains per pod (2.5 grains pod ${ }^{-1}$ ) $($ Table 2). Phosphorus is essential for the cell nucleus during cell division as it is involved in meristem tissue development, particularly in the early rapid stage of growth. $\mathrm{P}$ also affects rooting,

Table 2. Grain number per pod (GP) and haulm yield (HY) as affected by phosphorus rate and Pseudomonas fluorescens strain

\begin{tabular}{|c|c|c|}
\hline Traits & $\begin{array}{c}\text { GP } \\
\left(\text { No. } \text { pod }^{-1}\right)\end{array}$ & $\begin{array}{c}\mathrm{HY} \\
\left(\mathrm{Kg} \mathrm{ha}^{-1}\right)\end{array}$ \\
\hline \multicolumn{3}{|l|}{ Phosphorus rates $\left(\mathrm{kg} \mathrm{ha}^{-1}\right)$} \\
\hline 0 & 2.5 & 1332 \\
\hline 25 & 2.7 & 1378 \\
\hline $\operatorname{LSD}(0.05)$ & 0.1 & 109 \\
\hline \multicolumn{3}{|l|}{ Pseudomonas fluorescens strains } \\
\hline Un-inoculation & 2.5 & 1102 \\
\hline Pseudomonas fluorescens strain 136 & 2.5 & 1294 \\
\hline Pseudomonas fluorescens strain 168 & 2.8 & 1670 \\
\hline LSD (0.05) & 0.1 & 134 \\
\hline
\end{tabular}


photosynthesis, increases storage substances, transfer of carbohydrates, successful breeding and fruit set, color and coarseness and prematurity of fruits. The number of grains per pod has been shown to increase as the $\mathrm{P}$ applied increased (Turk and Tawaha (2002).

\section{Hundred grain weight}

ANOVA showed that the effect of $\mathrm{P}$ application on 100-grain weight was not significant. The effect of P. fluorescens strain and the interaction of the two factors were significant (Table 1). In the absence of $\mathrm{P}$, the 100-grain weight was significantly lower for un-inoculated plants than for plants inoculated with both strains (Figure 5). As shown, the highest 100-grain weight was achieved using a P content of $25 \mathrm{~kg} \mathrm{ha}^{-1}$ and seed inoculation with $P$. fluorescens strain 168 (Figure 5). Zeidan (2007) suggested that application of $\mathrm{P}$ at $0-60 \mathrm{~kg} \mathrm{ha}^{-1}$ contributes to nutrient absorption (phosphorus, potassium, magnesium and zinc) caused by the increase in soluble phosphorus and assimilation of nutrients to the grain, resulting in larger grains. This could be the reason for the increased 100-grain weight. At low fertilizer treatments, a decrease in 100-grain weight resulted from the competition for nutrients and the decrease in carbohydrate stores. Increased soluble P content increased the amount of phytin stored in the seeds. Phyitin serves as the main source of stored $\mathrm{P}$ in most grains and is an important compound for germination and seed growth with a significant contribution to seed size and weight.

\section{Pod length}

ANOVA indicated that pod length was significantly influenced by $\mathrm{P}$ application and $P$. fluorescens strain and by their interactive effect (Table 1). In the absence of phosphorus $P$. fluorescens strain 136 produced the longest pod length (12.22

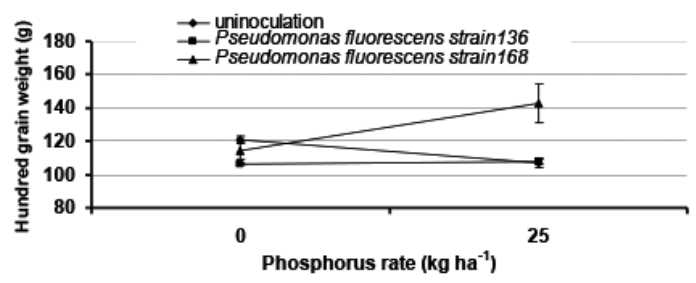

Figure 5. phosphorous rate $\times$ Pseudomonas fluorescens strain interaction effect on 100-grain weight. Vertical bars represent $\pm 1 \mathrm{SE}$ of means. \pm 0.17 ), and plants inoculated with $P$. fluorescens strain $168(11.54 \pm 0.38)$ and un-inoculated plants $(11.35 \pm 0.19)$ produced the shortest pod lengths (Figure 6). After application of $\mathrm{P}\left(25 \mathrm{~kg} \mathrm{ha}^{-1}\right)$, plants inoculated with $P$. fluorescens strains 168 and 136 showed the longest pod lengths of $14.37 \pm 0.19$ and $13.95 \pm 0.47$, respectively. The shortest pod length $(11.72 \pm 0.28)$ was observed in un-inoculated plants (Figure 6). Kazemi-Poshtmasari et al. (2007) also concluded that application of $\mathrm{P}$ fertilizers increased the pod length of the faba bean.

\section{Haulm yield}

ANOVA indicated that only the effect of the $P$. fluorescens strain was significant for haulm yield (Table 1). The highest haulm yield (1670 kg ha) was obtained from $P$. fluorescens strain 168 and the lowest yield $\left(1102 \mathrm{~kg} \mathrm{ha}^{-1}\right)$ was recorded for the un-inoculated plants (Table 2). Dey et al. (2004) reported that $P$. fluorescens trains increased haulm yield in the peanut. Sharma et al. (2003) suggested that the increase in shoot weight of the mung bean resulted from application of bacteria.

\section{Pod and grain yields}

ANOVA showed that pod yield was significantly influenced by the effects of $\mathrm{P}$ application, $P$. fluorescens strain and their interaction (Table 1). In the absence of $\mathrm{P}$, the highest pod yield was recorded for plants inoculated with $P$. fluorescens strain 168 and lowest was recorded for the uninoculated plants (Figure 7). When $\mathrm{P}$ was applied $\left(25 \mathrm{~kg} \mathrm{ha}^{-1}\right)$, pod yield increased significantly for plants inoculated with $P$. fluorescens strain 168 (Figure 7). The greatest pod yield was obtained with a P application of $25 \mathrm{~kg} \mathrm{ha}^{-1}$ for plants inoculated with P. fluorescens strain 168. ANOVA also showed that grain yield was significantly $(P \leq 0.01)$ influenced

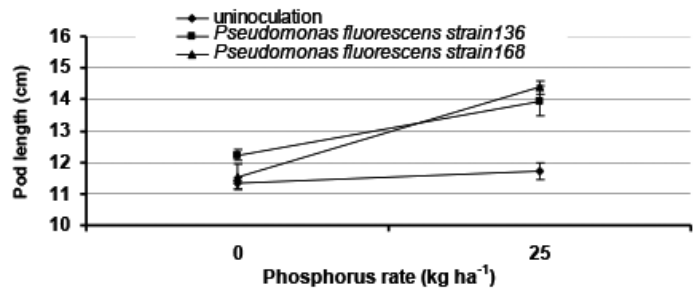

Figure 6. phosphorous rate $\times$ Pseudomonas fluorescens strain interaction effect on pod length. Vertical bars represent $\pm 1 \mathrm{SE}$ of means. 


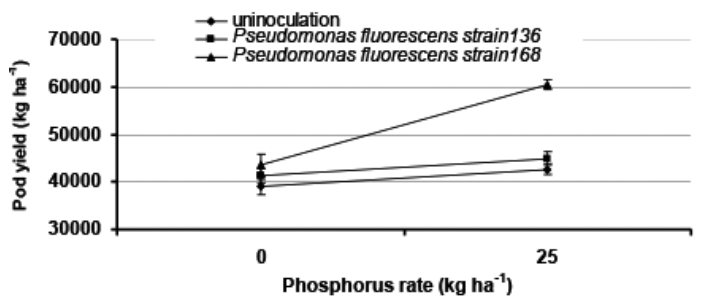

Figure 7. phosphorous application $\times$ Pseudomonas fluorescens strain interaction effect on pod yield. Vertical bars represent \pm $1 \mathrm{SE}$ of means.

by $\mathrm{P}$ application, $P$. fluorescens strain, and their interaction (Table 1). In the absence of phosphorus, grain yield with both Pseudomonas strains showed no significant difference from that of un-inoculated plants (Figure 8). With application of $\mathrm{P}$ fertilizer $\left(25 \mathrm{~kg} \mathrm{ha}^{-1}\right)$, grain yield for plants inoculated with P. fluorescens strain 168 increased by $42 \%$ over plants inoculated with $P$. fluorescens strain 136 and $65 \%$ over un-inoculated plants. Phosphorus is an essential macronutrient which promotes root growth and stimulates its lateral branching; this increases a plant's ability to absorb nutrients from the soil. Phosphorus also plays a vital role in flower formation and fruit set and in processes such as sugar and starch utilization, photosynthesis, cell division and nodule formation. Phosphorus increases the leaf area index by increasing leaf cell division, elongation and leaf number (Assuero et al., 2004; Kavanova et al., 2006); this increases light interception and photosynthesis assimilation, which increases plant biomass accumulation. Phosphorus also improves nitrogen metabolism in plants (Li and Zhao, 1990). Several groups of soil bacteria such as Pseudomonas exhibit phosphatesolubilizing ability through production of organic

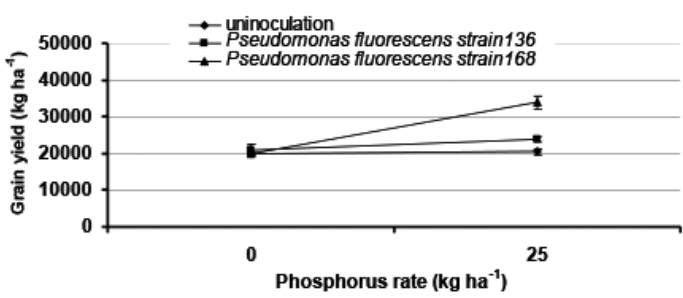

Figure 8. phosphorous application $\times$ Pseudomonas fluorescens strain interaction effect on grain yield. Vertical bars represent \pm 1 SE of means.

acids (Shaharoona et al., 2008). By changing the environmental acidity and enzymatic processes, they release the insoluble $\mathrm{P}$ of soil in the form of organic phosphoric acid, which increases its mobility in the soil (Chung et al., 2005; Gulati et al., 2010). These bacteria can decrease soil $\mathrm{pH}$ during phosphate solubilization (Shaharoona et al., 2008). Previous studies have found qualitative-quantitative improvements in the grain yield of crops from seed inoculation with phosphate-solubilizing bacteria (Afzal ea al., 2010; Saharan et al., 2010; Crowley, 2006; Dey et al., 2004).

\section{Conclusions}

The results of this study showed that the effect of phosphorus application and $P$. fluorescens strain was significant for grain/pod yield and most yield components of the faba bean. Seed inoculation with $P$. fluorescens strain 168 resulted in higher yield and yield components than $P$. fluorescens strain 136. The results of this experiment indicate that $P$. fluorescens strain 168 and application of phosphorus at a rate of $25 \mathrm{~kg} \mathrm{ha}^{-1}$ are recommended to achieve maximum grain and pod yields of the faba bean.

\section{Literature Cited}

Assuero, S.G.; Mollier, A.; Pellerin, S.

2004. The decrease in growth of phosphorus-deficient maize leaves is related to a lower cell production. Plant, Cell and Environment, 27: 887-895.

Bhattacharyya, P.N.; Jha, D.K.

2012. Plant growth-promoting rhizobacteria (PGPR): emergence in agriculture. World Journal of Microbiology and Biotechnology, 28:1327-1350.

Bolland, M.D.A.; Siddique, K.H.M.; Brennen, R.F.

2000 Grain yield responses of faba bean (Vicia faba L.) to applications fertilizer phosphorus and zinc. Australian Journal Experimental Agriculture, 40(6): 849-857.
Braud, A.; Je'ze'quel, K.; Bazot, S.; Lebeau, T.

2009. Enhanced phytoextraction of an agricultural $\mathrm{Cr}-, \mathrm{Hg}$ - and $\mathrm{Pb}$-contaminated soil by bioaugmentation with siderophore producing bacteria. Chemosphere, 74: 280-286.

Chung, H.; Park, M.; Madhaiyan, M.; Seshadri, S.; Song, J.; Cho, H.; Sa, T.

2005. Isolation and characterization of phosphate solubilizing bacteria from the rhizosphere of crop plants of Korea. Soil Biology and Biochemistry, 37: 1970-1974.

Crowley, D.

2006. Microbial Siderophores in the Plant Rhizosphere. In Barton L. L.; Abadía J. (Eds.). Iron Nutrition in Plants and 
Rhizospheric Microorganisms, Springer, Netherlands. pp. 169-198.

Dey, R.; Pal, K.K.; Bhatt, D.M.; Chauhan, S.M.

2004. Growth promotion and yield enhancement of peanut (Arachis hypogaea L.) by application of plant growthpromoting rhizobacteria. Microbiological Research, 159: 371-394.

Feng, K.; Lu, H.M.; Sheng, H.J.; Wang, X.L.; Mao, J.

2004. Effect of organic ligands on biological availability of inorganic phosphorus in soils. Pedosphere, 14(1): 85-92.

Gulati, A.; Sharma, N.; Vyas, P.; Sood, S.; Rahi, P.; Pathania,

V.; Prasad, R.

2010. Organic acid production and plant growth promotion as a function of phosphate solubilization by Acinetobacter rhizosphaerae strain BIHB 723 isolated from the cold deserts of the trans-Himalayas. Archive der Microbiology, 192: 975-983.

Jilani, G.; Akram, A.; Ali, R.M.; Hafeez F.Y.; Shamsi, I.H.; Chaudhry, A.N.; Chaudhry A.G.

2007. Enhancing crop growth, nutrients availability, economics and beneficial rhizosphere microflora through organic and biofertilizers. Annuals of Microbiology, 57:177-183.

Kavanova', M.; Lattanzi, F.A.; Grimoldi, A.A.; Schnyder, H. 2006. Phosphorus Deficiency Decreases Cell Division and Elongation in Grass Leaves. Plant Physiology, 141:766-775.

Li, S.X.; Zhao, B.S.

1990. The effect of soil nitrogen supplying capacity on phosphate fertilizer efficiency for some legume and nonlegume crops. Soil and Fertilizers 4: 19-23.

McBeath, T.M.; Smernik, R.J.; Lombi, E.Y.; McLaughlin, M.J. 2006. Hydrolysis of pyrophosphate in a highly calcareous soil: A solid-state phosphorus-31 NMR study. Soil Science Society of American Journal, 70: 856-862.

Raghothama, K.G.; Karthikeyan, A.S.

2005. Phosphate acquisition. Plant and Soil, 274: 37-49.

Rashid, M.; Khalil, S.; Ayub, N.; Alam S.; Latif F.

2004. Organic acids productionand phosphate solubilization by phosphate solubilizing microorganisms (PSM) under invitro conditions. Pakistan Journal of Biological Science, 7:187-196.

Saharan, K.; Sarma, M.V.R.K.; Srivastava, R.; Sharma, A.K.; Johri, B.N.; Prakash, A.; Sahai, V.; Bisaria, V.S.

2010. Development of non-sterile inorganic carrier-based formulations of fluorescent pseudomonad R62 and R81 and evaluation of their efficacy on agricultural crops. Applied Soil Ecology, 46: 251-258.

Saravanakumara, D.; Vijayakumarc, C.; Kumarb, N.; Samiyappan, R. 2007. PGPR-induced defense responses in the tea plant against blister blight disease. Crop Protection, 26: 556-565.
Shaharoona, B.; Naveed, M.; Arshad, M.; Zahir, Z.A.

2008. Fertilizer-dependent efficiency of Pseudomonads for improving growth, yield, and nutrient use efficiency of wheat (Triticum aestivum L.). Applied Microbiology and Biotechnology, 79: 147-155.

Sharma, A.; Johria, B.N.; Sharmab, A.K.; Glick, B.R.

2003. Plant growth-promoting bacterium Pseudomonas sp. strain GRP3 influences iron acquisition in mung bean (Vigna radiata L. Wilzeck). Soil Biology and Biochemistry, 35: 887-894.

Turk., M.A.; Tawaha, A.R.M.

2002 Impact of seeding rate, seeding date, rate and method of phosphorus application in faba bean (Vicia faba L. minor) in the absence of moisture stress. Biotechnology, Agronomy and Social and Environment, 6 (3): 171-178.

Wani, S.P.; McGill, W.B.; Haugenkozyra, K.L.; Robertson, J.A.; Thurston, J.J.

1994. Improved soil quality and barley yields with fababeans, manure, forages and crop rotation on a gray luvisol. Canadian Journal of Soil Science, 74: 75-84.

Yazdani M.; Bahmanyar, M.A.; Pirdashti, H.; Esmaili, M.A. 2009. Effect of Phosphate solubilization microorganisms (PSM) and plant growth promoting rhizobacteria (PGPR) on yield and yield components of Corn (Zea mays L.). Proceeding of World Academic Science, Engineering and Technology, 37:90-92.

Zeidan, M. S.

2007. Effect of organic manure and phosphorus fertilizers on growth, yield and quality of lentil plants in sandy soil. Research Journal of Agricultural and Biological Science, 3(6): 748-752.

Kazemi-Poshtmasari, H.; Pirdashti, H.; bahmanyar, M.A. 2007. Effect of mineral and biologic phosphorous fertilizers on agronomic properties of two broad bean (Vicia faba L.) cultivars. Agricultural and Natural Resources Sciences journal, 14(6): 21-33.

Son, T.T.N.; Diep, C.N.; Giang, T.T.M.; Thu, T.T.

2007. Effect of co-inoculants (Bradyrhizobia and phosphate solubilizing bacteria) liquid on soybean under rice based cropping system in the mekong delta. Omon Rice, 15:135-143.

Afzal, A.; Bano, A.; Fatima, M.

2010. Higher soybean yield by inoculation with N-fixing and P-solubilizing bacteria. Agronomy for Sustainable Development, 30 (2): 487-495.

Singh, A.; Baoule, A.L.; Ahmed, H.G.; Aliyu, U.; and Sokoto, M.B. 2011. Influence of phosphorus on the performance of cowpea (Vigna unguiculata (L.) Walp) varieties in the sudan savannah of Nigeria. Agricultural Sciences, 2: 313-317. 
